\title{
MORPHOLOGICAL AND BIOCHEMICAL DIVERSITY AND RESPONSE OF EGYPTIAN FABA BEAN TO HEAT AND DROUGHT STRESSES
}

\author{
M. A. Belal ${ }^{(1)}$, Samah M. M. Eldemery ${ }^{(2)}$, Y. A. Khidr ${ }^{(1)}$ and K. F. Abdellatif ${ }^{(1)^{\star}}$ \\ (1) Plant Biotech. Dept., GEBRI, USC, Egypt, \\ (2) Mol. Biol. Dept., GEBRI, USC, Egypt, \\ "Corresponding Author: kamal2004gr@yahoo.com
}

Received: Jul. 8, 2018

Accepted: Jul. 24,2018

\begin{abstract}
Four Egyptian faba bean (Vicia faba L.) varieties ("Giza843", "Giza716", "Misr1" and "Sakha1") have been evaluated under heat and drought stresses using seventeen morphological traits and total protein content. Analysis of variance of the morphological trait revealed highly significant differences among treatments and genotypes for all studied traits and the interaction between genotypes and treatment was also significant. Both varieties "Giza716" and "Giza843" gave the highest means for most of the morphological traits. The control treatment surpass all the other treatments in the most of the morphological traits. The lowest significant means were obtained from the heat with drought treatment while the effect of heat on the morphological traits was less than the effect of drought stress. According to the cluster analysis of both morphological and biochemical data, the varieties "Giza716" and "Giza843" were clustered together on one group where the varieties "Misr1" and "Sakha1" were clustered in another group. A protein band of molecular weight of about $76 \mathrm{kDa}$ was noticed in the protein pattern of the variety "Giza716" (heat with drought treatment) and of about $100 \mathrm{kDa}$ was obtained in the protein pattern of the variety "Giza843" (heat with drought treatment). The morphological and biochemical parameters along with susceptibility test revealed that "Giza716" and "Giza843" appeared to be tolerant for drought and heat. However "Misr1" and "Sakha1" varieties appeared to be susceptible.
\end{abstract}

Key words: Faba bean genotypes, Morphological traits, Heat, Drought, Stress, total protein analysis

\section{INTRODUCTION}

Faba bean (Vicia faba L.) is a worldwide important legume crop, a diploid species with $2 n=12$ chromosomes and belong to the family of Fabaceae (leguminosae), subfamily of Papilionoideae, tribe of Viceae.

Environmental abiotic stresses, such as drought, extreme temperature, cold, heavy metals or high salinity and biotic stresses such as insects, broomrape, fungi, bacteria etc. cause several effects to faba bean at morphological, molecular and biochemical levels. Faba bean is more sensitive to drought than some other grain legumes including common bean, pea and chickpea (McDonald and
Paulsen 1997; Amede and Schubert 2003). The reduction in faba bean seed yield was positively related to the amount of water reduction and reach up to $50 \%$ of seed yield (Musallam et al., 2004; Ouda et al., 2010; Ammar et al., 2014 and Afiah et al., 2016). All of them stated that drought had negative effects on faba bean yield and its components. In addition, Abid et al., (2017) reported that drought stress reduced plant growth and affected physiological parameters whereas the plant response to drought stress significantly varied in the studied faba bean cultivars.

Faba bean plants bear heat stress when subjected to supra-optimal 
temperatures or stressed by drought, mostly at the end of the growing season Stoddard et al. (2006). The reproductive stage of faba bean is also sensitive to heat stress (Patrick and Stoddard, 2010). Siddiqui et al. (2015) studied the effects of various levels of temperature (control, mild, and modest) on plant height (ph), fresh weight (fw), dry weight $(\mathrm{dw})$ and leaf area in ten faba been genotypes and they found that the variety "C5" was the most heat stress tolerant whereas the "Espan" variety was the most heat stress sensitive genotypes.

The combined effect of both heat and drought stresses induce significant alterations in plant biochemistry and metabolism (Apel and Hirt, 2004). The possible responses under environmental stresses may cause membrane injuries, protein degradation; enzyme inactivation and induce oxidative stress (Zlatev and Lidon 2012). To study these alterations, Sodium Dodecyle sulfate polyacrylamide gel electrophoresis (SDS-PAGE) was used to differentiate between cultivars of faba bean exposed to environmental stress (Stegmann et al., 1980; Shaddad \& El-Tayeb, 1990; Abdellatif et al., 2012, Zakaria et al., 2015 and Eldemery et al., 2016).

The aim of this research was to evaluate the ability of Egyptian faba bean genotypes to tolerate the heat and/or drought stresses at both morphological and biochemical levels and determine specific protein bands related to tolerant genotypes.

\section{MATERIAL AND METHODS}

The present work was carried out at the
Plant Molecular biology Laboratory, Genetic Engineering and Biotechnology Research Institute, University of Sadat City, Sadat City, Egypt, during the period of 2015 to 2018.

\section{Plant material}

Four Egyptian faba bean (Vicia faba L.) varieties obtained from Sakha Agricultural Research station, Agriculture Research Center, Egypt have been used in this study. Their pedigrees are presented in Table (1).

\section{Field Experiment}

The field experiment has been carried out during growing seasons 2016-2017 and 2017-2018. The experiments were performed at the farm of Genetic Engineering and Biotechnology Research Institute, University of Sadat City, Egypt. Seeds of each variety were planted in six bags, every bag contained two seeds. Four treatments have been applied for the cultivated varieties. The first treatment was the (control) which cultivated at 15 November and was irrigated each two days. The second treatment was the (drought) that cultivated at 15 November and was irrigated one a week. The third treatment was the (heat) which cultivated at 15 January and was irrigated each two days. The fourth treatment was the (drought with heat) that cultivated at 15 January and was irrigated once a week. Seventeen morphological characteristics were measured during all the period of plants growth according to literature (Terzopoulos and Bebeli 2008; Leht, 2009; El-Absawy et al., 2012 and Abdellatif et al., 2012).

Table 1: Faba bean varieties, origin, and pedigree used in the study.

\begin{tabular}{|l|l|l|l|}
\hline No & Varity & Origin & Pedigree \\
\hline 1 & Giza843 & Egypt & Cross 461 x cross561 \\
\hline 2 & Giza716 & Egypt & $(83 / 453 / 503 \times 83 / 824 / 461)$ \\
\hline
\end{tabular}




\begin{tabular}{|l|l|l|l|}
\hline 3 & Misr1 & Egypt & $(123 \mathrm{~A} / 45 / 76 X G .3) \times(62 / 1570 / 66 \times G .2) \times($ Romi $\times$ Habashi $)$ \\
\hline 4 & Sakha1 & Egypt & $(85 / 283 / 620 \times 88 / 724 / 716)$ \\
\hline
\end{tabular}

Biochemical Marker analysis Sodium Dodecyle Sulfate Polyacrylamide Gel Electrophoresis (SDS-PAGE) technique was used to study the protein banding patterns of four tested varieties of (Vicia faba L.). Total protein was extracted according to the method of (Laemmli, 1970). Leaves of faba bean samples collected from the treated plants (control, drought, heat and heat with drought) were used for the total protein extraction. The protein patterns of different treatments of faba bean were compared using SDS-PAGE method to identify the protein bands associated with drought and heat stress in faba bean.

\section{Data Scoring and Statistical Analysis}

The morphological traits of faba bean have been evaluated in a completely randomized design (CRD) with five repetitions for each treatment. Data from morphological experiment were subjected to analysis of variance (ANOVA) to determine variation among the varieties using $\mathrm{JMP}{ }^{\circledR} 7.0$ software (Sall et al., 2007).

The means were compared by Least Significant Difference (LSD) of the treatments at $5 \%$ probability level. The two-way multivariate hierarchical cluster analysis has been done also using JMP ${ }^{\circledR}$ 7.0 software. An equation was used to calculate the sensitivity of the varieties to heat and drought stress: Susceptibility coefficient $=\Sigma$ (Treatment mean - Control mean). The susceptibility to the whole environmental stresses has been significantly tested using LSD values in JMP® 7.0 software.

Protein pattern was photographed with digital camera and the photos were handled with Adobe Photoshop 9 (CS2) software in order to adjust the contrast and the brightness. The Protein bands were scored as " 1 " and " 0 ", whereas " 1 " stands for the presence and " 0 " stands for the absence of bands. Specific bands have been determined for specific cultivars. Cluster analysis has been made for the collected data of protein pattern bands of different stresses along with the control. A dendrogram was generated from the similarity matrix using the unweighted pair group method with arithmetic in NTSYSpc 2.0 software (Rohlf, 2000).

\section{RESULTS AND DISCUSSION Analysis of variance (ANOVA) of the morphological traits}

Analysis of variance of the morphological traits was carried out in order to detect the significant differences among the genotypes; treatments and the interaction between genotypes and treatments for all the morphological traits. The data revealed highly significant differences among the genotypes; treatments and the interaction between genotypes and treatments for all the morphological traits (Table 2).

Our results are in agreement with different results obtained on faba bean. Alghamdi, (2009) found significant variance in drought stress tolerance among the genotypes of faba bean. Moreover, Ouji et al., (2011) determined genetic variability in nine Tunisian faba bean populations belonging to three botanical classes (Var. minor, var. equina and var. major) using twenty-seven agromorphological traits. They noted significant differences between populations for most agro-morphological traits in four main groups. Furthermore, Abdellatif et al., (2012) evaluated eight economical Egyptian faba beans varieties 


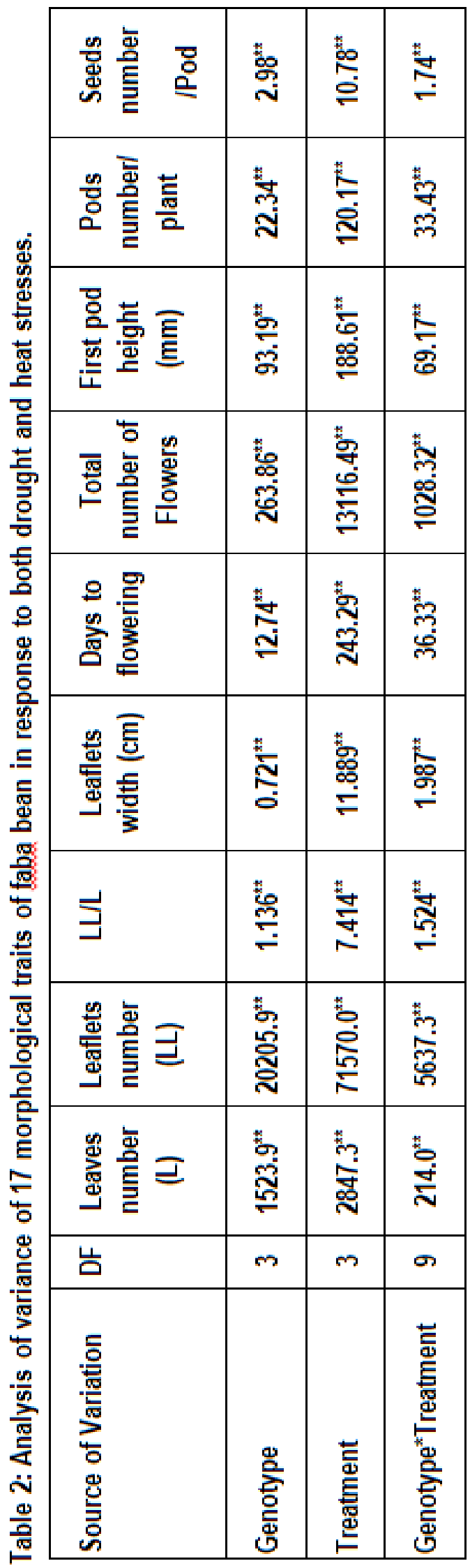

\begin{tabular}{|c|c|c|c|c|}
\hline 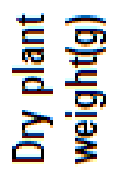 & & 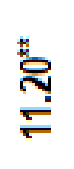 & $\frac{7}{\frac{7}{6}}$ & 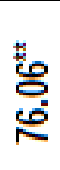 \\
\hline 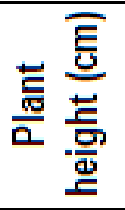 & & 葛 & 苛 & 望 \\
\hline 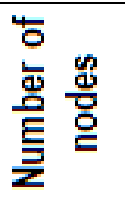 & & 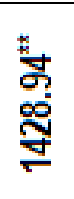 & 㣽 & ஜே \\
\hline 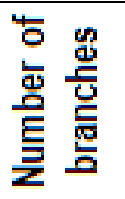 & & $\underset{\infty}{\stackrel{*}{5}}$ & 葛 & लֶ, \\
\hline 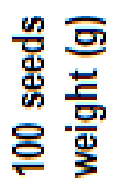 & & 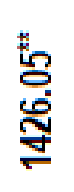 & 苞 & స్ \\
\hline 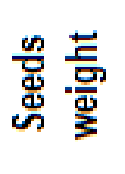 & $\begin{array}{l}\text { 홈 } \\
\text { 흠 } \\
\text { 흔 }\end{array}$ & 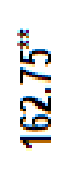 & $\frac{\text { : }}{\stackrel{0}{ \pm}}$ & 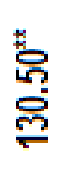 \\
\hline 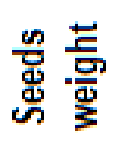 & $\begin{array}{l}\text { 호 } \\
\text { 흠 }\end{array}$ & 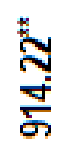 & $\frac{1}{\infty}$ & 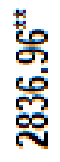 \\
\hline $\begin{array}{l}\text { 号 } \\
\text { 志 } \\
\text { 志 }\end{array}$ & 플 & 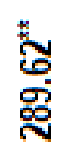 & ָָ๊ & 苛 \\
\hline 殅 & & $m$ & $m$ & $\sigma$ \\
\hline 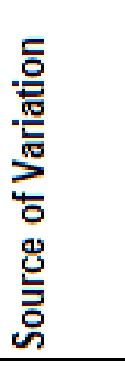 & & 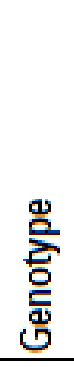 & 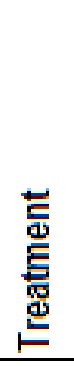 & 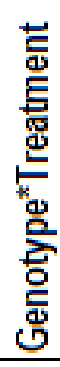 \\
\hline
\end{tabular}


results showed highly significant differences among all treatments and genotypes in most of studied traits and revealed a negative correlation between the morphological traits and the drought tolerance. Abid et al., (2017) found

significant difference in morphological responses of 11 faba bean cultivars to drought stress.

\section{Least Significant Differences (LSD) values among faba bean genotypes}

LSD values of faba bean varieties illustrated significant differences among genotypes concerning drought and/or heat stresses in all measured morphological traits (Table 3). LSD showed the highest significant mean in total of seven traits (leaflets width, pods number/ plant, seeds number/pod, seeds number/plant, seeds weight/pod, seeds weight/plant and dry plant weight) and the lowest significant mean in one trait (100 seeds weight) in the variety "Giza843". In addition, the highest significant mean in total of seven traits (leaves number (L), leaflets number (LL), days to flowering, first pod height, number of branches, number of nodes and plant height) and the lowest significant mean in one trait (leaflets width) were recorded in the variety "Giza716". Furthermore, the variety "Misr1" revealed the highest significant mean in only one trait (100 seeds weight) and the lowest significant mean in 10 traits (leaves number, leaflet number, (LL/L), total number of flowers, first pod height, seeds number/pod, seeds weight/pod, number of branches, number of nodes and plant height). Moreover, the variety "Sakha1" exhibited the highest mean in two traits (LL/L and total number of flowers) and the lowest significant mean in six traits (days to flowering, pods number/ plant, seeds number/plant, seeds weight/pod, seeds weight/plant and plant weight (Table 3).

These results indicate that "Giza716" and "Giza843" varieties displayed the highest significant means of the most the morphological traits (13 out of 17 traits) including the yield and its components (Table 3). On the other hand, "Sakha1" and "Misr1" varieties manifested the lowest significant means. This might be an indicator for drought and/or heat tolerance of "Giza716" and "Giza843" varieties. Our results are similar to the results obtained by Link et al., (1999) who found significant variance in drought stress tolerance among the genotypes of faba bean. Likewise, Abdelmula and Abuanja (2007) evaluated the performance of 22 faba bean genotypes under heat stress and stated that the genetic variability, yield stability and correlations among yield, yield components and other vegetative traits were significantly different among genotypes for most of the agronomic characters.

\section{Least Significant Differences (LSD) values among the treatments means}

The significant differences among means of the four treatments (control, drought, heat and drought with heat) were investigated and presented in Table (4). According to the LSD values, the control treatment exhibited the highest significant means in 13 out of 17 traits (leaves number, leaflets number, LL/L, total number of flowers, pods number/ plant, seeds number/pod, seeds number/plant, seeds weight/pod, seeds weight/plant, 100 seeds weight, number of nodes, plant height and dry plant weight) and the lowest significant mean in only one trait (first pod height). While, drought treatment revealed the highest significant means in only one trait (days to flowering) and the lowest significant 
M. A. Belal, et al.,

mean in two traits (leaflets width and

number of branches). Whereas, heat

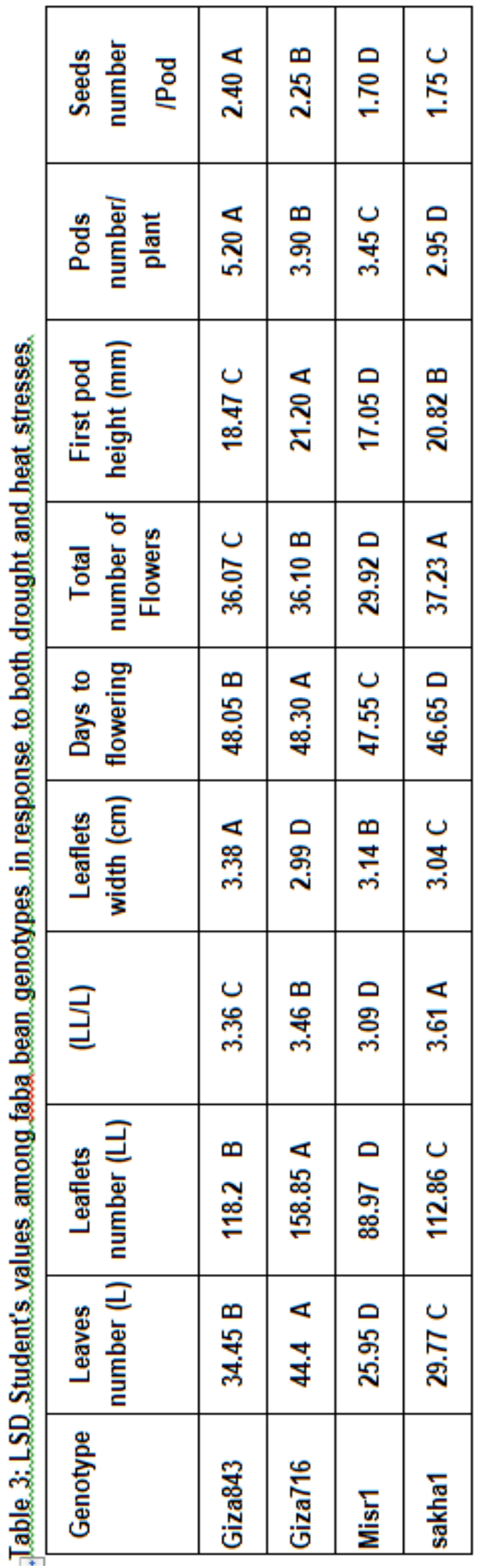

\begin{tabular}{|c|c|c|c|c|}
\hline 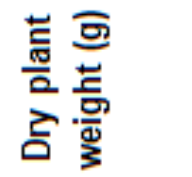 & 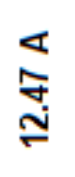 & $\begin{array}{l}\infty \\
\stackrel{\infty}{\circ} \\
\stackrel{\text { ஸे }}{\sim}\end{array}$ & $\begin{array}{l}\stackrel{\cup}{N} \\
\stackrel{2}{E}\end{array}$ & 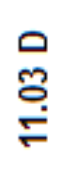 \\
\hline 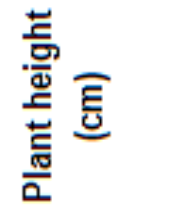 & 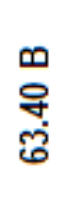 & $\begin{array}{l}\varangle \\
\text { ๙్ } \\
\text { గెర }\end{array}$ & $\begin{array}{l}0 \\
\text { ñ } \\
\text { กิ }\end{array}$ & $\underset{\text { हn }}{\sim}$ \\
\hline 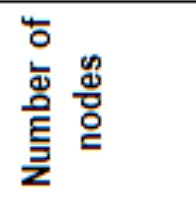 & $\begin{array}{l}\text { ص } \\
\stackrel{2}{\sim} \\
\stackrel{\text { mj }}{m}\end{array}$ & \begin{tabular}{l}
$\varangle$ \\
$\infty$ \\
$\infty$ \\
\multirow{j}{*}{}
\end{tabular} & $\begin{array}{l}0 \\
\text { ̊ి } \\
\text { ஸे }\end{array}$ & 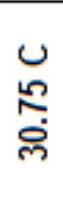 \\
\hline 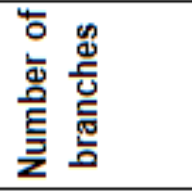 & 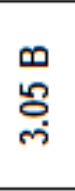 & 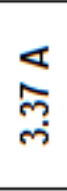 & $\stackrel{0}{\frac{n}{2}}$ & 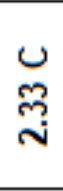 \\
\hline 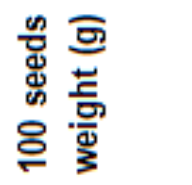 & $\begin{array}{l}0 \\
\emptyset \\
\check{n}\end{array}$ & $\begin{array}{l}\infty \\
\stackrel{2}{0} \\
8 \\
8\end{array}$ & $\begin{array}{l}\stackrel{\leftarrow}{2} \\
\stackrel{2}{2}\end{array}$ & 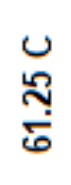 \\
\hline 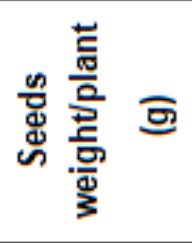 & 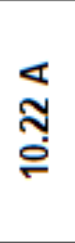 & $\begin{array}{l}\infty \\
\text { gै } \\
\text { g. }\end{array}$ & $\begin{array}{l}\text { U } \\
\text { के }\end{array}$ & $\begin{array}{l}\text { D } \\
\text { के } \\
\text { ले }\end{array}$ \\
\hline 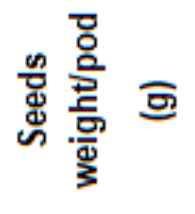 & 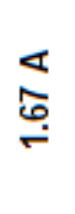 & $\begin{array}{l}\infty \\
\stackrel{\rho}{+}\end{array}$ & $\begin{array}{l}\cup \\
\stackrel{2}{-}\end{array}$ & $\stackrel{\circ}{\stackrel{D}{\Gamma}}$ \\
\hline 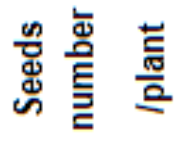 & $\begin{array}{l}\varangle \\
\stackrel{\square}{0} \\
\tilde{\sigma}\end{array}$ & 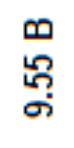 & 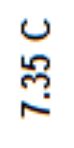 & $\begin{array}{l}0 \\
8 \\
8\end{array}$ \\
\hline 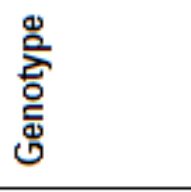 & 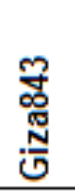 & $\begin{array}{l}\underset{N}{N} \\
\text { iñ }\end{array}$ & 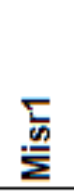 & 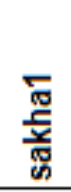 \\
\hline
\end{tabular}


treatment displayed the highest significant means in three traits (leaflets width, first pod height, and number of branches) and the lowest significant means in two traits (days to flowering and 100 seeds weight). On the other hand, heat with drought treatment revealed the lowest significant means in 12 traits (leaves number (L), leaflets

number (LL), LL/L, total number of flowers, pods number/ plant, seeds number/pod, seeds number/plant, seeds weight/pod, seeds weight/plant, number of nodes, plant height and dry plant weight, Table 4).

Thus, it can be stated that control treatment surpasses the other treatments in most of the morphological traits. On the others hand, the combined treatment of drought with heat stresses showed the lowest significant means in most of the morphological traits. In addition, the effect of heat stress on the morphological traits is less than the drought stress effect (Table 4). Our results are similar to the results obtained by Al-Suhaibani (2009) who assessed the effect of water regimes on faba bean cultivar "Giza 957" at four different growth stages encompassing its entire life cycle. The results manifested that water deficit significantly influenced seed yield and quality of faba bean. Furthermore, Siddiqui et al., (2015) estimated the morphological traits (plant height (PH), fresh weight (FW) and dry weight (DW), leaf area) of different faba bean genotypes under different levels of drought stresses. The results revealed that drought stress reduced all growth parameters.

\section{LSD values of interaction between genotypes and treatments}

The interaction between genotypes and treatment was significant in all the investigated morphological traits (Table 2). The highest significant mean (59.4) obtained from the variety "Giza716" with the control treatment, while the lowest significant mean (13.8) was observed on variety "Misr1" with the combined treatment (heat with drought) in the number of leaves trait (Table 5 ). In the number of leaflets the highest significant mean (252.8) obtained from the variety "Giza716" with control treatment, however, the slightest significant mean (31.9) was observed on variety "Misr1" with the combined treatment (heat with drought). For $L L / L$, the highest significant mean (4.23) obtained from the variety "Sakha1" in control treatment whereas, the lowest significant mean (2.31) was observed on variety "Misr1" with the combined treatment (heat with drought). The highest significant mean (4.30) obtained from the variety "Giza843" with heat treatment while the smallest significant mean (2.28) was observed on variety "Giza716" with drought treatment in the leaflets width. For days to flowering trait, the highest significant mean (53.0) obtained from the variety "Giza716" in control treatment whereas the lowest significant mean (42.4) was observed on variety "Giza716" in heat treatment. For total number of flowers trait, the highest significant mean (81.2) obtained from the variety "Sakha1" in control treatment while the lowest significant mean (42.4) was observed on variety "Misr1" in heat with drought treatment. For first pod height trait, the highest significant mean (25.0) obtained from the variety "Sakha1" in heat with drought treatment while the least significant mean was (13.2) noted on variety "Misr1" in control treatment. For pods number/ plant, the highest significant mean (9.2) obtained from the variety "Giza843" in control treatment while the lowest significant mean (1.0) was recorded on variety "Misr1" in heat with drought treatment. For seeds number/pod, the highest significant mean (3.0) obtained from the variety "Giza843" 
M. A. Belal, et al.,

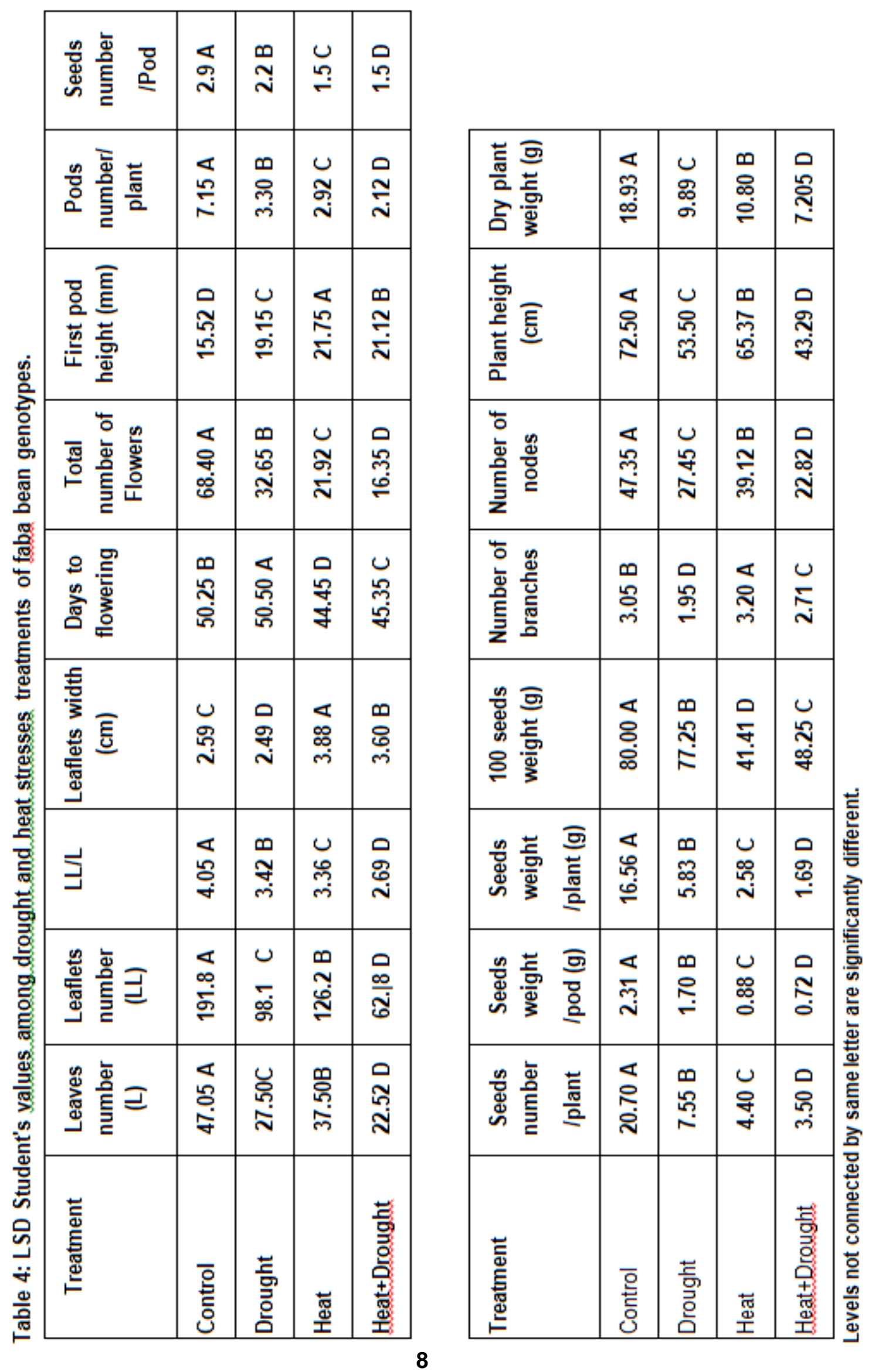




\begin{tabular}{|c|c|c|c|c|c|c|c|c|c|c|c|c|c|c|c|c|}
\hline 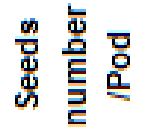 & 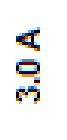 & $\begin{array}{l}\stackrel{0}{0} \\
\stackrel{0}{i}\end{array}$ & 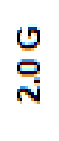 & $\begin{array}{l}0 \\
\text { i } \\
\end{array}$ & $\begin{array}{c}\varangle \\
0 \\
\text { ri }\end{array}$ & $\begin{array}{l}\text { U } \\
\text { O }\end{array}$ & $\begin{array}{l}\text { U } \\
\text { i }\end{array}$ & $\begin{array}{l}0 \\
\text { i } \\
\end{array}$ & $\begin{array}{l}u \\
\dot{0} \\
i\end{array}$ & 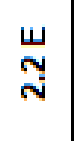 & $\stackrel{\bar{o}}{\circ}$ & 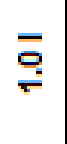 & $\begin{array}{l}\infty \\
\stackrel{\infty}{\circ} \\
\stackrel{\text { N }}{2}\end{array}$ & $\begin{array}{l}x \\
\text { 오 }\end{array}$ & 을 & $\stackrel{x}{\stackrel{x}{-}}$ \\
\hline 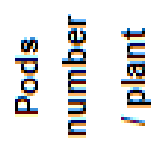 & $\underset{\sigma}{\overleftarrow{\sigma}}$ & 모․ & 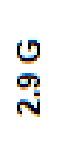 & $\overrightarrow{\mathrm{n}}$ & $\begin{array}{l}0 \\
0 \\
i\end{array}$ & $\overline{\stackrel{\omega}{N}}$ & 㟔 & $\begin{array}{l}u \\
\text { Oे } \\
\text { ले }\end{array}$ & $\underset{\infty}{\sim}$ & $\stackrel{\vec{\infty}}{=}$ & $\begin{array}{l}I \\
\text { o } \\
\text { N }\end{array}$ & $\begin{array}{l}\Sigma \\
\stackrel{0}{-}\end{array}$ & $\underset{\sim}{\stackrel{\sim}{\sim}}$ & $\overline{\stackrel{\omega}{N}}$ & 岂 & $\begin{array}{l}\text { Y } \\
\text { 은 }\end{array}$ \\
\hline 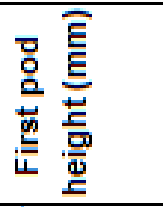 & $\begin{array}{l}\overrightarrow{1} \\
\stackrel{0}{\circ} \\
\stackrel{0}{\sigma}\end{array}$ & $\begin{array}{l}\Sigma \\
0 \\
0 \\
0 \\
\end{array}$ & ֶָ & $\begin{array}{l}\bar{\circ} \\
\Phi\end{array}$ & $\begin{array}{l}\stackrel{x}{0} \\
\stackrel{\tilde{C}}{=}\end{array}$ & 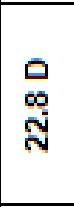 & $\begin{array}{l}\infty \\
\text { సై } \\
\text { స్ }\end{array}$ & $\frac{L}{\stackrel{n}{n}}$ & $\begin{array}{l}\text { O } \\
\text { ָै } \\
\stackrel{5}{=}\end{array}$ & $\begin{array}{l}\overrightarrow{0} \\
\stackrel{0}{\sigma} \\
\stackrel{\sigma}{\sigma}\end{array}$ & \begin{tabular}{l}
7 \\
0 \\
$\infty$ \\
\hdashline
\end{tabular} & $\begin{array}{l}\text { I } \\
\circ \\
\\
\end{array}$ & $\underset{⿱ 乛}{\underline{\sigma}}$ & 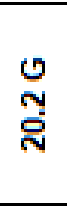 & $\begin{array}{l}\text { U } \\
\text { స్ }\end{array}$ & $\begin{array}{l}\varangle \\
0 \\
\text { 常 }\end{array}$ \\
\hline 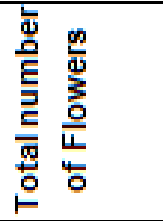 & $\begin{array}{l}0 \\
\stackrel{0}{\circ} \\
\dot{6}\end{array}$ & $\overline{\text { స్ }}$ & $\begin{array}{l}\text { L } \\
\text { 它 }\end{array}$ & 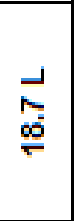 & $\begin{array}{l}0 \\
0 \\
0 \\
\dot{0}\end{array}$ & $\begin{array}{l}0 \\
\infty \\
\text { ก̃ }\end{array}$ & $\begin{array}{l}7 \\
\text { ปิ }\end{array}$ & 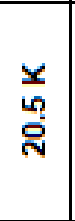 & $\begin{array}{l}0 \\
\infty \\
\dot{d} \\
0\end{array}$ & $\begin{array}{l}I \\
\stackrel{0}{-} \\
m\end{array}$ & $\begin{array}{l}0 \\
0 \\
\stackrel{5}{ }\end{array}$ & $\begin{array}{l}\stackrel{\circ}{\circ} \\
\stackrel{\circ}{\circ}\end{array}$ & 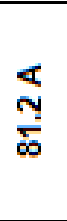 & $\underset{⿱ ⺌ 冖}{\omega}$ & $\begin{array}{l}z \\
\infty \\
\dot{q} \\
\end{array}$ & 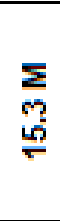 \\
\hline 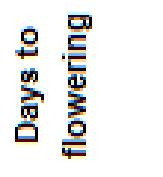 & 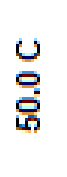 & $\begin{array}{l}\infty \\
0 \\
\dot{5} \\
\dot{5}\end{array}$ & $\begin{array}{l}4 \\
\infty \\
\infty \\
\text { So }\end{array}$ & $\begin{array}{l}x \\
\dot{d} \\
0 \\
\text { gे }\end{array}$ & $\begin{array}{l}\varangle \\
\vdots \\
0 \\
\text { గi } \\
\text { in }\end{array}$ & $\begin{array}{l}\infty \\
0 \\
\dot{5}\end{array}$ & $\begin{array}{l}\stackrel{y}{Y} \\
\stackrel{y}{Z}\end{array}$ & $\begin{array}{l}山 \\
\infty \\
\infty \\
\dot{\sigma}\end{array}$ & $\begin{array}{l}0 \\
0 \\
0 \\
0\end{array}$ & $\begin{array}{l}0 \\
0 \\
0 \\
\end{array}$ & $\begin{array}{l}0 \\
0 \\
0 \\
0 \\
0\end{array}$ & $\begin{array}{l}\bar{o} \\
\dot{j}\end{array}$ & $\begin{array}{l}0 \\
\text { 음 } \\
\text { ơ }\end{array}$ & $\begin{array}{l}0 \\
\text { ○्் }\end{array}$ & $\begin{array}{l}\overrightarrow{0} \\
\text { j }\end{array}$ & $\begin{array}{l}\overline{0} \\
\dot{j}\end{array}$ \\
\hline 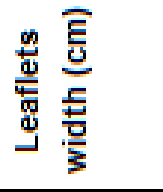 & 品 & 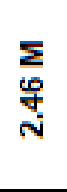 & 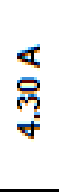 & $\begin{array}{l}\infty \\
\text { กิ } \\
\dot{v}\end{array}$ & $\begin{array}{l}\circ \\
\text { ํ. } \\
\text { in }\end{array}$ & $\begin{array}{l}\text { a } \\
\stackrel{2}{\text { ป }} \\
\text { N }\end{array}$ & $\begin{array}{l}u \\
\stackrel{0}{O} \\
\dot{+}\end{array}$ & $\begin{array}{l}4 \\
\text { gे } \\
\text { ले }\end{array}$ & $\begin{array}{l}\vec{T} \\
\stackrel{+}{d} \\
\stackrel{N}{ }\end{array}$ & $\begin{array}{l}z \\
\text { Jे } \\
\text { j. }\end{array}$ & 뭉 & 峁 & $\begin{array}{l}Y \\
\stackrel{0}{0} \\
\stackrel{i}{j}\end{array}$ & $\begin{array}{l}\bar{\infty} \\
\stackrel{\text { N }}{\text { on }}\end{array}$ & जे & 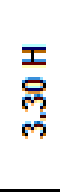 \\
\hline 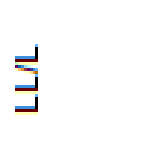 & 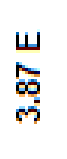 & స్ల్ల & I & $\begin{array}{l}\Sigma \\
\text { g } \\
\text { N }\end{array}$ & $\begin{array}{l}\infty \\
\text { กิ } \\
\dot{v}\end{array}$ & טn & $\stackrel{\square}{ㅇ}$ & मे & 吕 & \begin{tabular}{l}
$z$ \\
\multirow{2}{N}{} \\
J
\end{tabular} & ָ̊ & $\stackrel{a}{\mathrm{n}}$ & 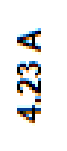 & 汖 & 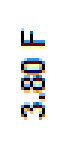 & 筞 \\
\hline 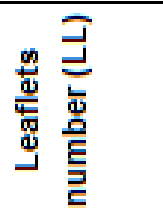 & $\begin{array}{l}0 \\
\circ \\
\dot{0} \\
\stackrel{0}{-}\end{array}$ & 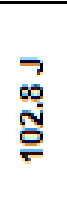 & $\begin{array}{l}\text { س } \\
\stackrel{0}{0} \\
\text { g }\end{array}$ & $\begin{array}{l}z \\
0 \\
\dot{\Xi} \\
\dot{\Phi}\end{array}$ & 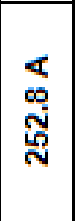 & $\begin{array}{l}0 \\
0 \\
\dot{0} \\
\dot{0} \\
\stackrel{5}{5}\end{array}$ & $\begin{array}{l}I \\
0 \\
\dot{0} \\
\stackrel{m}{-}\end{array}$ & $\begin{array}{l}\overline{0} \\
\stackrel{\circ}{\circ}\end{array}$ & $\begin{array}{l}0 \\
0 \\
0 \\
0 \\
\stackrel{0}{6}\end{array}$ & 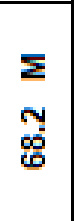 & $\begin{array}{l}x \\
\infty \\
\text { ઠे }\end{array}$ & $\begin{array}{l}a \\
\frac{a}{5} \\
\end{array}$ & $\begin{array}{l}\infty \\
\stackrel{\varpi}{\dot{m}} \\
\stackrel{\varpi}{\sigma}\end{array}$ & $\begin{array}{l}- \\
\qquad \\
\infty \\
\dot{\sigma}\end{array}$ & $\begin{array}{l}u \\
0 \\
0 \\
\text { o } \\
\text { m. }\end{array}$ & 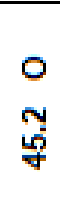 \\
\hline 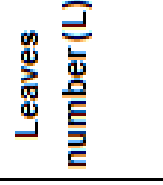 & $\begin{array}{l}\text { ㅁ } \\
\text { o } \\
\text { gे }\end{array}$ & 롤 & $\begin{array}{l}\text { 늠 } \\
\text { ํ. }\end{array}$ & $\stackrel{\vec{d}}{\dot{N}}$ & 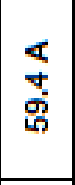 & $\begin{array}{l}0 \\
0 \\
0 \\
\tilde{m}\end{array}$ & $\begin{array}{l}\infty \\
\circ \\
\dot{j}\end{array}$ & $\begin{array}{l}I \\
\dot{0} \\
\dot{b} \\
\end{array}$ & \begin{tabular}{l}
$山$ \\
$\stackrel{v}{ }$ \\
\multirow{J}{*}{}
\end{tabular} & $\begin{array}{l}\Sigma \\
0 \\
\Phi \\
\stackrel{\sigma}{\sigma}\end{array}$ & $\begin{array}{l}\text { Y } \\
\text { O } \\
\text { : }\end{array}$ & 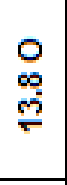 & $\begin{array}{l}\text { U } \\
\text { ț } \\
\text { g }\end{array}$ & $\stackrel{+}{\stackrel{\sim}{*}}$ & 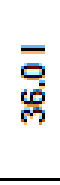 & $\begin{array}{l}\mathbf{z} \\
\text { o } \\
\text { o }\end{array}$ \\
\hline 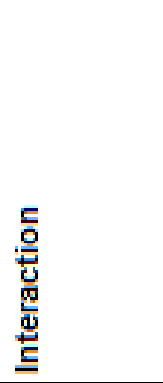 & 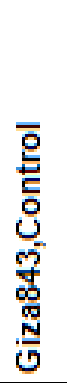 & 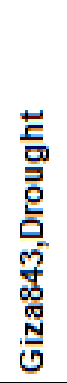 & 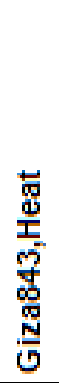 & 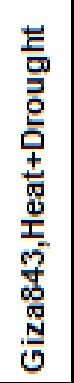 & 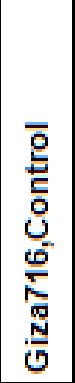 & 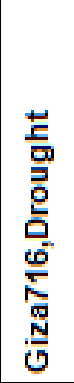 & 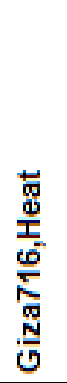 & 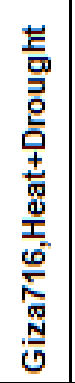 & 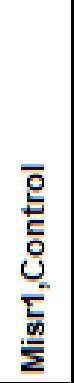 & 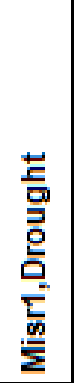 & 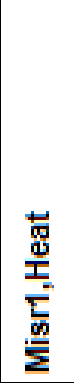 & 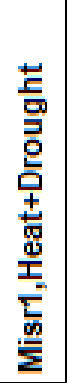 & 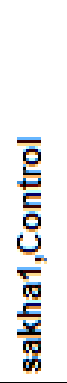 & 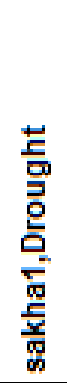 & 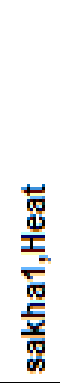 & 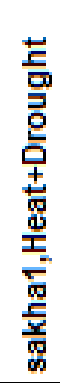 \\
\hline
\end{tabular}




\begin{tabular}{|c|c|c|c|c|c|c|c|c|c|c|c|c|c|c|c|c|}
\hline 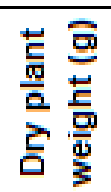 & $\begin{array}{l}\infty \\
\text { J } \\
\text { ¿ें }\end{array}$ & $\begin{array}{l}0 \\
\stackrel{0}{\circ}\end{array}$ & 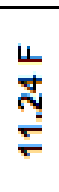 & $\begin{array}{l}\mathbf{z} \\
\underset{\sim}{N}\end{array}$ & 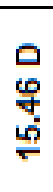 & $\begin{array}{l}x \\
\text { 웅 } \\
\text { 음 }\end{array}$ & 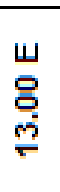 & $\begin{array}{l}x \\
\dot{\omega} \\
\tilde{\omega}\end{array}$ & 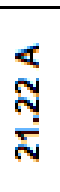 & $\begin{array}{l}\Sigma \\
\stackrel{\Sigma}{N} \\
\Gamma\end{array}$ & 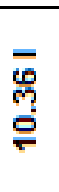 & $\begin{array}{l}0 \\
\overline{0} \\
\dot{0}\end{array}$ & 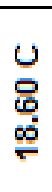 & $\begin{array}{l}\text { ָุ } \\
\text { స్ㅁ }\end{array}$ & 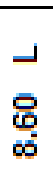 & $\begin{array}{l}0 \\
\ddot{B} \\
\dot{0}\end{array}$ \\
\hline 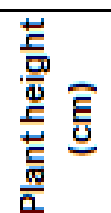 & $\begin{array}{l}\infty \\
\stackrel{t}{0} \\
\stackrel{n}{n}\end{array}$ & $\begin{array}{l}0 \\
0 \\
0\end{array}$ & $\begin{array}{l}\text { 山 } \\
0 \\
8 \\
0\end{array}$ & $\begin{array}{l}\Sigma \\
\text { Na } \\
\text { J }\end{array}$ & 过 & 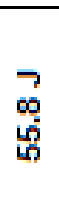 & $\begin{array}{l}u \\
\text { p. }\end{array}$ & 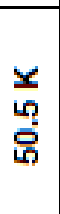 & $\begin{array}{l}0 \\
\text { مo } \\
\text { م }\end{array}$ & $\begin{array}{l}z \\
\text { y } \\
\text { J }\end{array}$ & $\begin{array}{l}\text { I } \\
\text { n? } \\
80\end{array}$ & $\begin{array}{l}a \\
\underline{0} \\
\stackrel{0}{m}\end{array}$ & 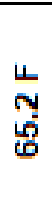 & 岁 & $\begin{array}{l}\overline{0} \\
\text { ¿̊. }\end{array}$ & $\begin{array}{l}\circ \\
\text { o } \\
\text { ळ్ }\end{array}$ \\
\hline
\end{tabular}

\begin{tabular}{|c|c|c|c|c|c|c|c|c|c|c|c|c|c|c|c|c|}
\hline 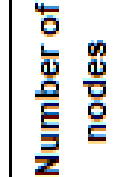 & $\begin{array}{l}0 \\
\text { Oొ } \\
\text { Jै }\end{array}$ & స్ & $\begin{array}{l}\text { U. } \\
\text { Oे }\end{array}$ & $\begin{array}{l}\sum \\
\infty \\
\infty \\
\vdots \\
\vdots\end{array}$ & 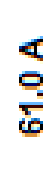 & $\begin{array}{l}\overline{\text { jे }} \\
\text { d }\end{array}$ & 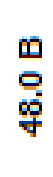 & $\begin{array}{l}I \\
0 \\
0 \\
\dot{0}\end{array}$ & 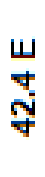 & $\begin{array}{l}\mathbf{z} \\
\infty \\
\text { ஸें }\end{array}$ & $\begin{array}{l}Y \\
\text { क्र } \\
\text { S }\end{array}$ & $\begin{array}{l}0 \\
\frac{0}{2} \\
\frac{0}{2}\end{array}$ & $\begin{array}{l}u \\
\dot{y} \\
\text { gे }\end{array}$ & ت̊ & $\begin{array}{l}0 \\
0 \\
0 \\
0 \\
0\end{array}$ & O \\
\hline
\end{tabular}

\begin{tabular}{|c|c|c|c|c|c|c|c|c|c|c|c|c|c|c|c|c|}
\hline 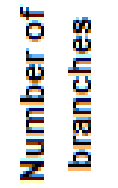 & $\begin{array}{l}0 \\
\dot{H} \\
\text { d }\end{array}$ & $\begin{array}{l}0 \\
\text { U. }\end{array}$ & $\begin{array}{l}\infty \\
\stackrel{0}{ } \\
\sim\end{array}$ & $\begin{array}{l}\underset{\sim}{\sim} \\
\stackrel{\infty}{N}\end{array}$ & $\begin{array}{l}\infty \\
\stackrel{\infty}{\rho}\end{array}$ & $\stackrel{\frac{U}{0}}{\stackrel{0}{N}}$ & $\underset{\sim}{\ll}$ & ن. & $\begin{array}{l}\frac{L}{\omega} \\
\stackrel{\omega}{N}\end{array}$ & $\begin{array}{l}\mathbf{x} \\
\stackrel{y}{=}\end{array}$ & $\begin{array}{l}\frac{L}{0} \\
\stackrel{0}{N}\end{array}$ & $\bar{N}$ & $\begin{array}{l}\frac{L}{o} \\
\stackrel{\leftrightarrow}{N}\end{array}$ & & $\begin{array}{l}\underset{\sim}{W} \\
\stackrel{\infty}{N}\end{array}$ & $\begin{array}{l}I \\
\stackrel{2}{n}\end{array}$ \\
\hline
\end{tabular}

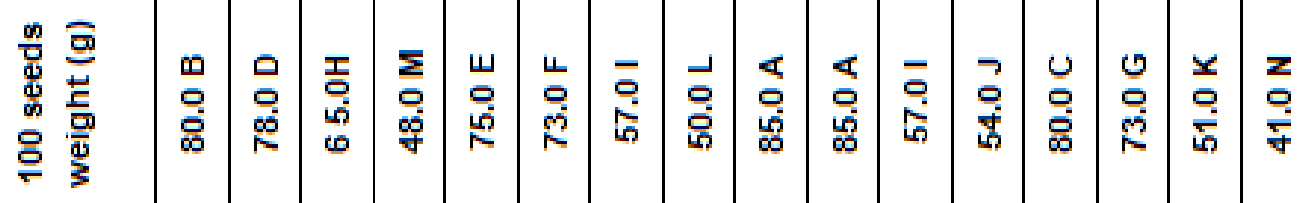

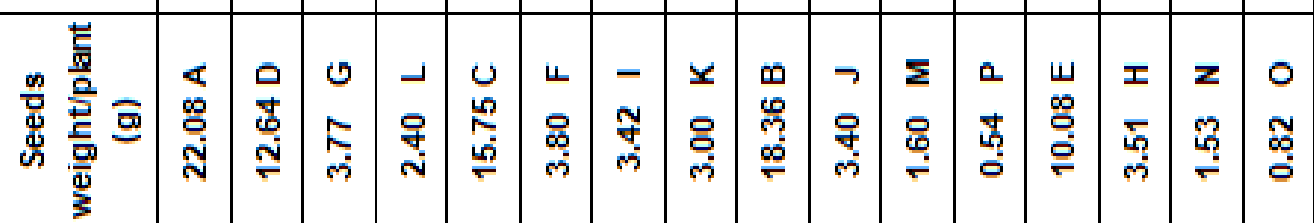

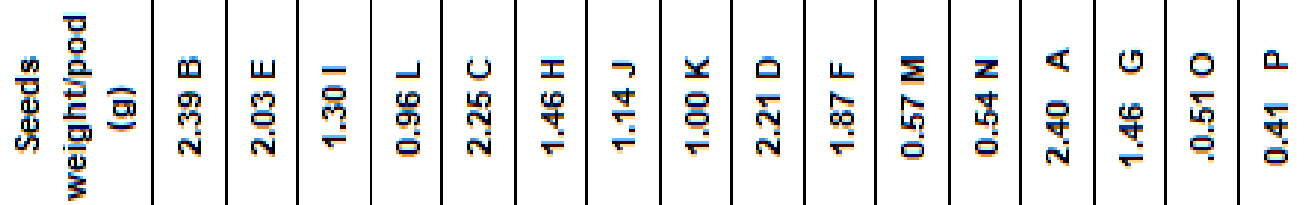

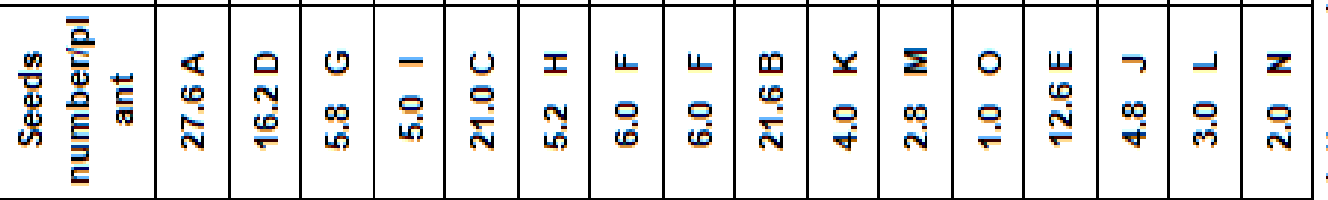

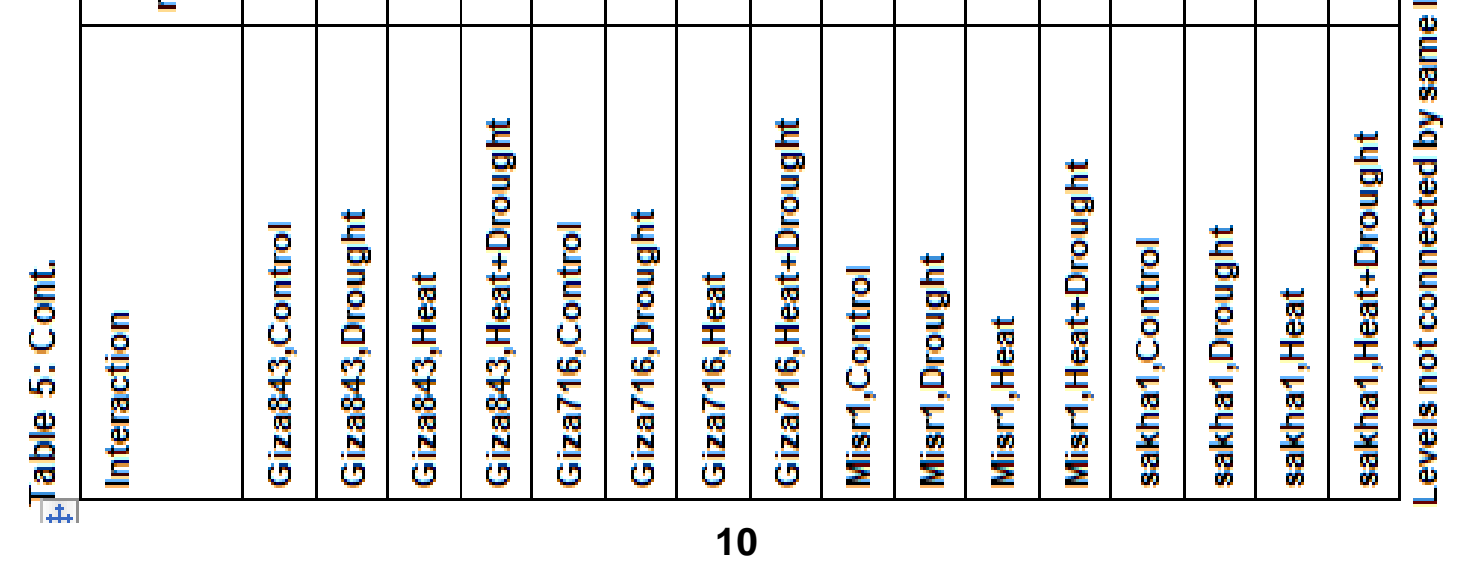


treatment. For seeds number/plant, the highest significant mean (27.6) obtained from the variety "Giza843" in control treatment while the lowest significant mean (1.0) was observed on variety "Misr1" in heat with drought treatment. For seeds weight/pod the highest significant mean $(2.40)$ obtained from the variety "Sakha1" in heat treatment whereas the lowest significant mean $(0.41)$ was scored for variety "Sakha1" in heat with drought treatment. For seeds weight/plant, the highest significant mean (22.08) obtained from the variety "Giza843" in control treatment while the lowest significant mean (0.54) was scored for variety "Misr1" in heat with drought treatment. For 100 seeds weight, the highest significant mean (85.0) obtained from the variety "Misr1" in control treatment and from "Misr1" in drought treatment while the lowest significant mean (41.0) was observed on variety "Sakha1" in heat with drought treatment. For number of branches, the highest significant mean (3.8) was scored for the variety "Giza716" in heat treatment while the lowest significant mean (1.2) was observed on variety "Misr1" in drought treatment. For number of nodes, the highest significant mean (61.0) was scored for the variety "Giza716" in control treatment; whereas the lowest significant mean (14.5) was marked on variety "Misr1" in heat with drought treatment. For plant height, the highest significant mean (76.4) was scored for the variety "Giza716" in control treatment while the lowest significant mean (5.61) was observed on variety "Misr1" in heat with drought treatment. For dry plant weight, the highest significant mean (21.22) obtained from the variety "Misr1" in control treatment while the lowest significant mean (5.61) was observed for the variety "Misr1" in heat with drought treatment.

It can be concluded that the control treatment in both varieties "Giza716" and
"Giza843" exhibited the highest significant means in most of the morphological traits (10 out of 17). On the other hand, the heat with drought treatment in the variety "Misr1" displayed the lowest significant means in most of the morphological traits 10 out of 17 , (Table 5). Thus, it can be summarized that the results of the interaction support the results of the main effects (genotypes and treatments separately). Our results are similar to those of Afiah et al., (2016) in their study on the response of five divergent faba bean genotypes namely ("NBL Mar 3", "NBL 5", “L 3", "Nubariya1" and "Misr1") to water stress on some morphological characteristics. They found wide range of differences among all genotypes in seed yield /plant and "NBL 5" was the most drought tolerant genotype while "Misr1" was the most sensitive one.

\section{Susceptibility test}

Determination of heat and drought tolerance of the faba bean varieties were investigated by application of drought and or heat treatments. The variety which exhibited stable results across both the different irrigation and heat treatments was considered as drought and heat tolerant variety and the variety which displayed unstable or variable results through the different treatments was considered as drought and heat susceptible variety according to (Cattivelli et al., 2008; Khan et al., 2010; Abdellatif et al., 2012, El-Absawy et al., 2012). An equation was used according to the previous references to detect the susceptibility of tested varieties to drought and heat stresses as following. Susceptibility coefficient $=\Sigma$ (Treatment mean - Control mean).

The Significant differences according to this equation were tested using LSD, the variety "Misr1" showed the highest significant susceptibility value to drought 
stress for the number of leaves (-65), number of pods (-16), seeds weight/plant $(-49.54)$, plant height $(-1.79)$, number of branching (-77.7), number of nodes (117.64) and seeds number/plant (-57) (Table 6). Thus, this variety could be considered as susceptible variety for drought and heat stress. On the other hand, the variety "Giza 843 " was the most significant tolerant to drought and heat in the number of leaves $(-34)$, leaflet number (-191.2), number of flowers (99.69), first pod height (6.7), seeds weight/pod (-2.88), 100 seeds weight ($39)$, dry plant weight (-33.4) and seeds number/plant. Thus, this variety could be considered as tolerant variety for drought and heat stress (Table 6).

\section{Morphological cluster analysis}

For morphological traits, the two-way hierarchical cluster analysis divided (in the first way of clustering) the Vicia faba varieties into two clusters, the first cluster contained "Giza843" and "Giza716" varieties (the environmental stress tolerant varieties), while the second cluster consisted of "Misr1" and "Sakha1" (susceptible varieties) (Figure 1). For morphological traits (in the second way of clustering), the cluster analysis divided the morphological traits into three cluster. The first cluster was divided into two sub clusters; the first sub cluster consisted of leaves number, number of nodes and leaflets number traits, while the second sub cluster contained days to flowering, seeds number/pods, dry plant weight, plant height and number of branching traits. The second cluster was divided into two sub clusters, the first sub cluster consisted of leaflets width traits, while the second sub cluster consisted of pods number, seeds number /plant and seeds weight /plant traits. The third cluster was divided into two sub cluster, the first sub cluster contained LL/L, numbers of flowers, first pods height and seeds weight /pods traits, while the second sub cluster contained 100 seeds weight trait (Figure 1).

It seems that the environmental stress tolerant varieties ("Giza843" and "Giza716") were aggregated in one cluster while the environmental susceptible varieties ("Misr1" and "Sakha1") were clustered together. These results are in harmony with those found with Abdellatif et al., (2012) and ElAbsawy et al., (2012). 
Menoufia J. Agric. Biotechnology, Vol. 3 October (2018): 1 - 18

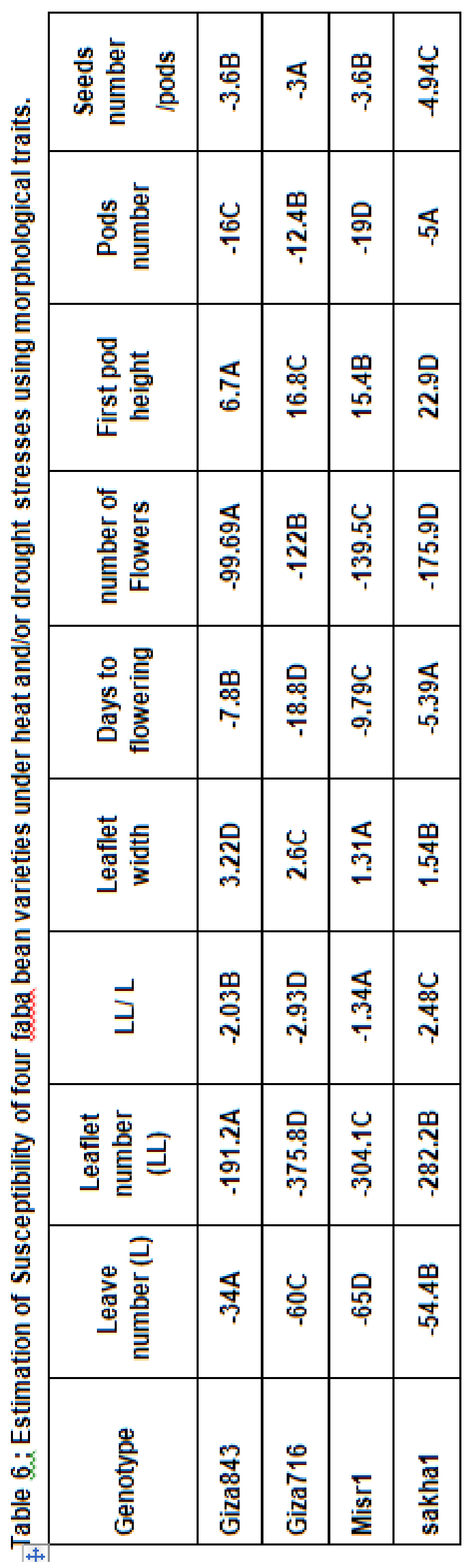

\begin{tabular}{|c|c|c|c|c|}
\hline 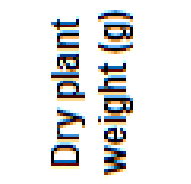 & 守 & 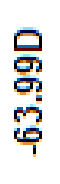 & ن্ৰ & 邑 \\
\hline $\begin{array}{l}\text { 흠 } \\
\text { 馬 } \\
\text { 듬 }\end{array}$ & $\underset{1}{\stackrel{u}{+}}$ & ১্ণ & 옴 & 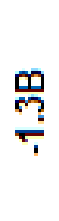 \\
\hline 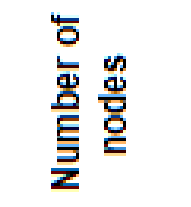 & 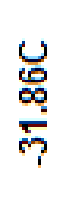 & 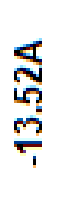 & $\begin{array}{l}\frac{\rho}{0} \\
\frac{1}{5}\end{array}$ & 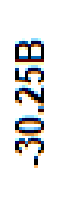 \\
\hline 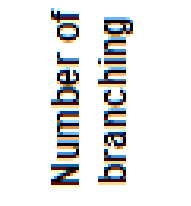 & $\begin{array}{l}\mathscr{9} \\
\stackrel{\infty}{q}\end{array}$ & $\begin{array}{l}\text { Uু } \\
\text { ণ্ }\end{array}$ & $\stackrel{R}{\stackrel{R}{N}}$ & $\begin{array}{l}\overleftarrow{\$} \\
\stackrel{5}{8}\end{array}$ \\
\hline 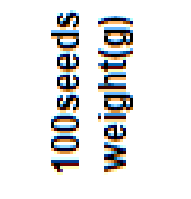 & శ్ & 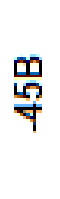 & ب & 육 \\
\hline 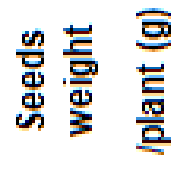 & v & 塄 & 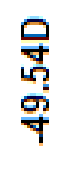 & 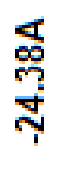 \\
\hline 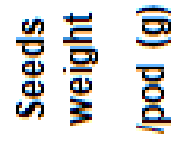 & $\begin{array}{l}\underset{\infty}{\infty} \\
\underset{\infty}{\infty}\end{array}$ & $\frac{\text { 号 }}{7}$ & 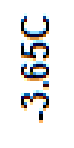 & 只 \\
\hline 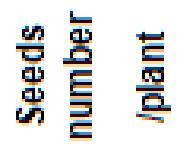 & 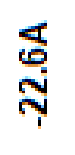 & $\begin{array}{l}\text { U } \\
\text { ఖ } \\
\text { Yे }\end{array}$ & 只 & 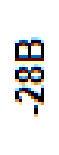 \\
\hline 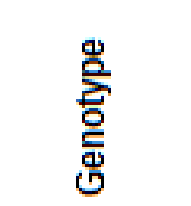 & $\begin{array}{l}\text { 筞 } \\
\text { 芯 }\end{array}$ & 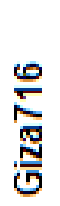 & $\frac{\overline{5}}{\Sigma}$ & 旁 \\
\hline
\end{tabular}


M. A. Belal, et al.,

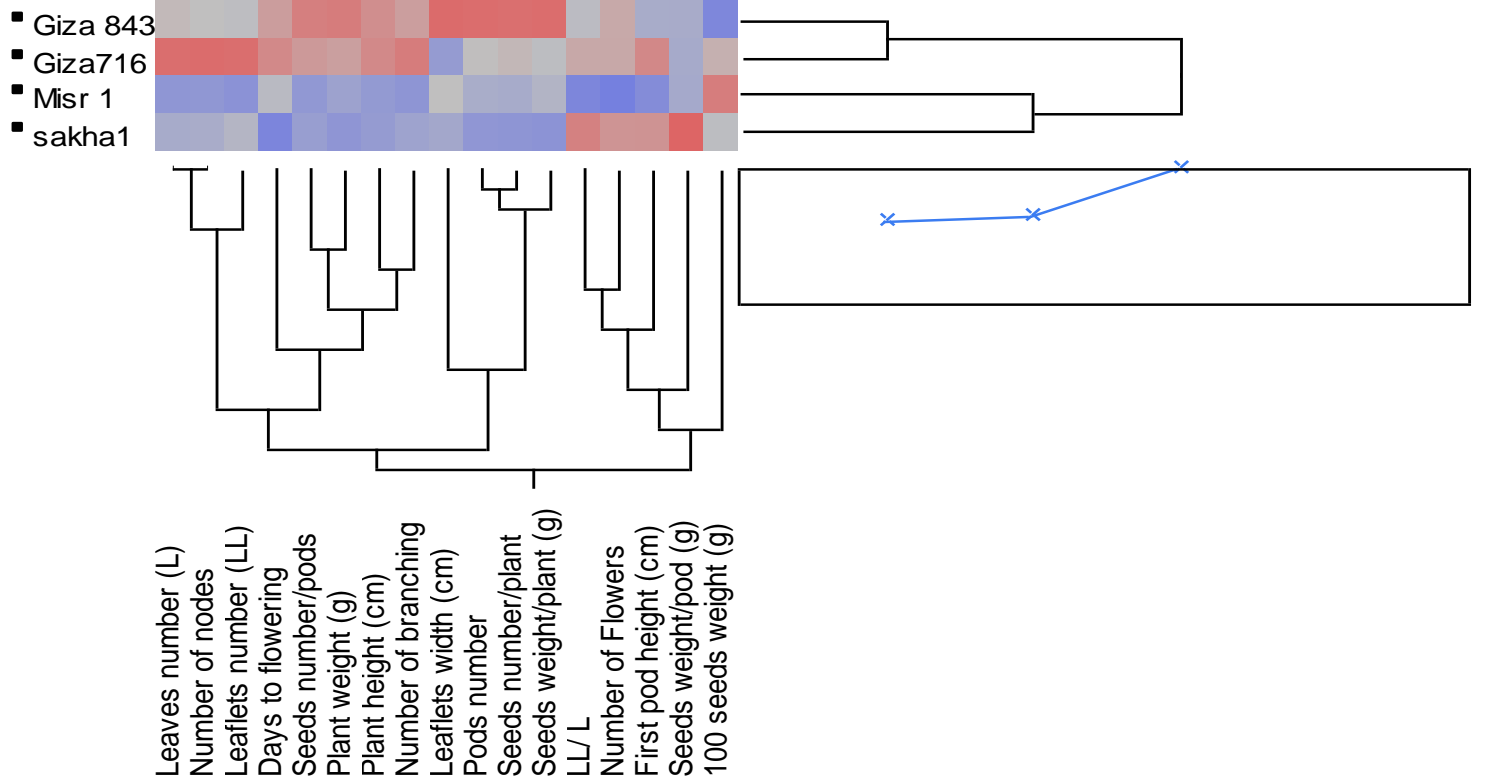

Figure 1: Two-way hierarchical cluster analysis of faba bean varieties and morphological traits under different levels of heat and drought stresses. 


\section{Biochemical analysis}

SDS-PAGE technique was used to study the protein banding patterns of four varieties of (Vicia faba L.) under drought and heat stresses. According to the protein analysis, a total of twenty-four bands were observed from the total protein pattern overall the cultivars. Some bands were identified that may be correlated with drought and/or heat tolerant in faba bean; whereas a band at about molecular weight of $78 \mathrm{kDa}$ has been noticed at the protein pattern of "Giza716" variety under heat and drought treatment (Figure 2). Another band at about molecular weight of $100 \mathrm{kDa}$ has been noticed from the total protein pattern of "Giza843" variety under heat and drought treatment. Those two bands were not found in the pattern of the other two varieties (Figure 2). These findings may support that both varieties
"Giza843" and "Giza716" accumulate proteins with different molecular weight in response to the environmental stresses which reflects their tolerance in different ways to that stresses. On the other hand, the varieties "Misr1" and "Sakha1" protein patterns have no changes which may reflects their negative to the environmental stresses. Similar results were reported in barely by Elrabey et al., (2009) and in wheat by Elsawy et al., (2015).

\section{Cluster analysis of protein data}

The results of cluster analysis of protein data for total treatment showed that the studied faba bean cultivars were divided into two clusters. The first cluster consisted of "Giza843" and "Giza716". The second cluster contained "Misr1" and "Sakha1" (Figure 3).

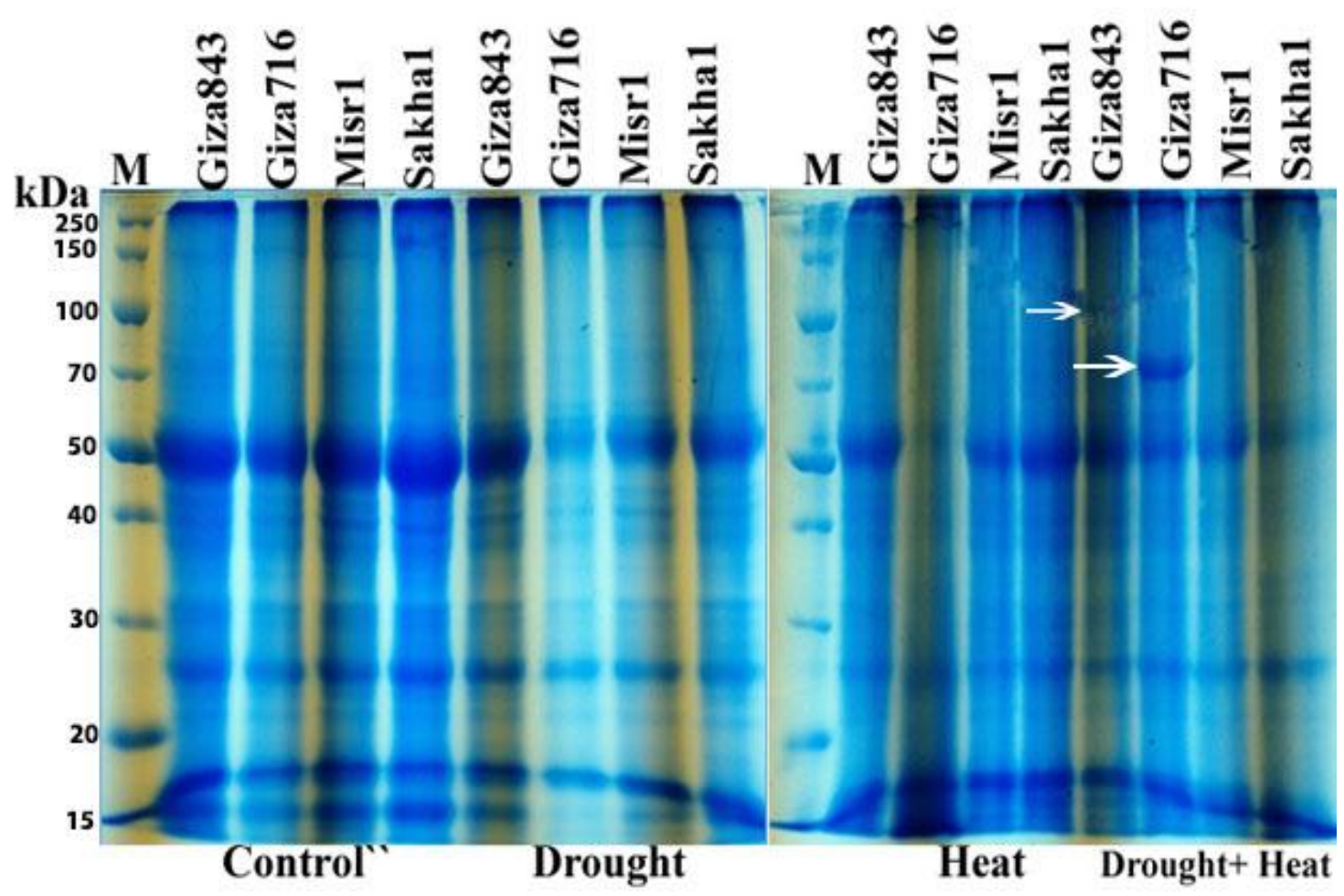

Figure 2: SDS-PAGE protein pattern of four drought and heat stressed faba bean varieties separated on $15 \%$ SDS-PAGE. 

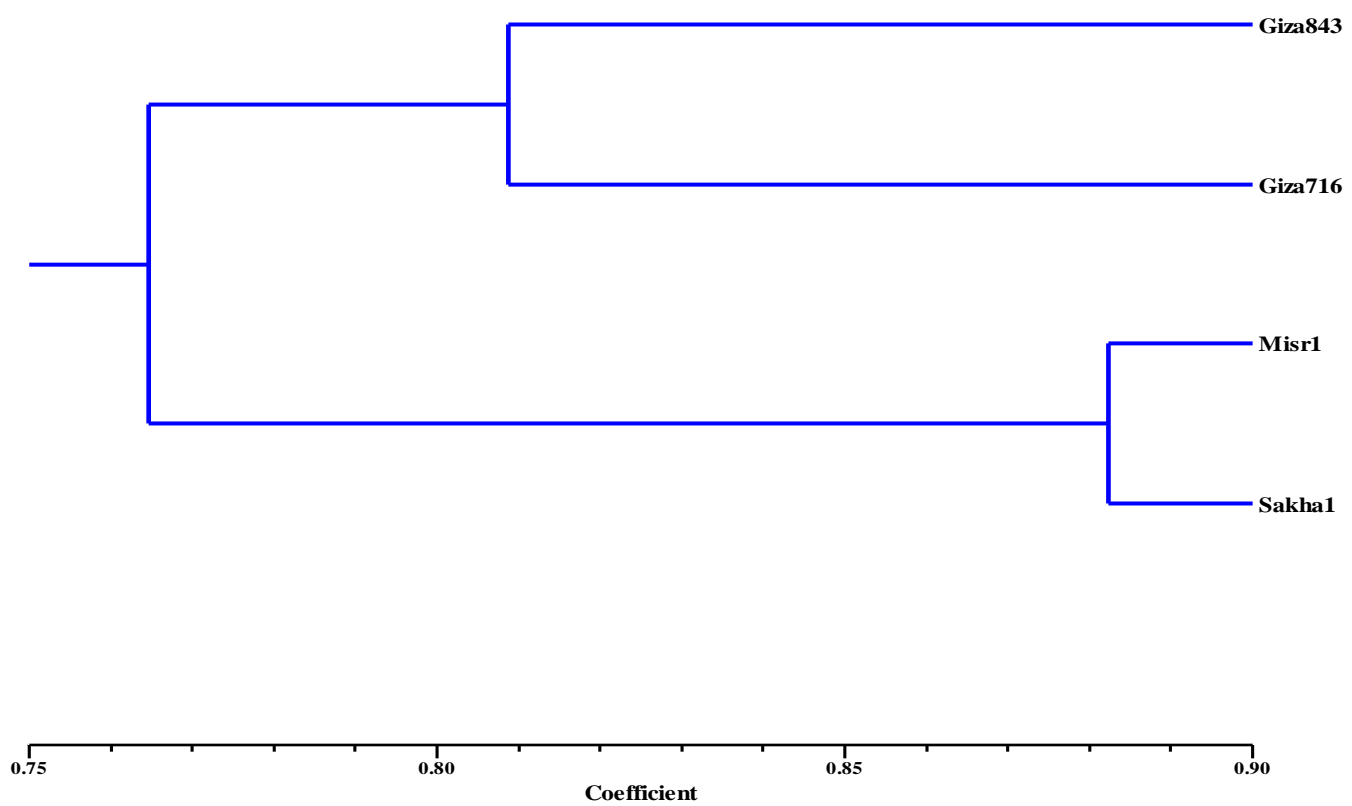

Figure 3: Dendrogram of total protein pattern in the four tested faba bean varieties.

These results support the results of morphological traits whereas they revealed that both varieties "Giza843" and "Giza716" are having protein patterns different from those of the varieties "Misr1" and "Sakha1". In addition, the latter are susceptible to both heat and drought stresses. Abdellatif et al., (2012) found that the protein pattern of the variety "Giza843" (the drought tolerant variety) is different from the protein pattern of the variety "Giza3" (the drought susceptible variety).

\section{REFERENCES}

Abdellatif, K.F., E.A. El-Absawy and A.M. Zakaria (2012). Drought stress tolerance of faba bean as studied by morphological traits and seed storage protein pattern. J. Plant Stud. 1, 47-54. Abdelmula, A.A. and I.K. Abuanja (2007). Genotypic responses yield stability, and association between characters among some of Sudanese Faba bean (Vicia faba L.) genotypes under heat stress. Proceedings of the Tropical
German Conference (Utilization of diversity in land use systems: Sustainable and organic approaches to meet human needs), Witzenhausen, 9-11 Oct 2007.

Abid, G., K. Hessini, M. Aouida, M. Aroua, J. Baudoin, Y. Muhovki, G. Mergeai, K. Sassi, M. Machraoui, F. Souissi and M. Jebara (2017). Agro-physiological and biochemical responses of faba bean (Vicia faba L. var. 'minor') genotypes to water deficit stress. Biotechnol. Agron. Soc. Environ. 21(2): 1-14.

Afiah, S.A., Z.A. Abd El- Gawad, T.R. Mohamed and H.H. Al-Agwany (2016). Salt and Water Deficit Tolerance in some (Vicia faba L.) Genotypes in Relation to Pigments, ISSR - PCR Markers and Stress Tolerance Indices. Egypt. J. Bot., 56(1).121 - 144.

Alghamdi, S. S. (2009). Chemical composition of faba bean (Vicia faba L.) genotypes under various water regimes. Pakistan Journal of Nutrition, 8(4): 477-482. 
Al-Suhaibani, N. A. (2009). Influence of early water deficit on seed yield and quality of faba bean under arid environment of Saudi Arabia. AmEurasian J Agric Environ Sci 5:649654

Amede, T. and S. Schubert (2003). Mechanisms of drought resistance in grain legumes. I. Osmotic adjustment. Ethiop. J. Sci., 26, 37-46.

Ammar, M.H., F. Anwar, E.H. El-Harty, H.M. Migdadi, S.M. Abdel-Khalik, S.A. Al-Faifi, M. Farooq and S.S. Alghamdi (2014). Physiological and yield responses of faba bean (Vicia faba L.) drought in a Mediterranean-type Environment. J Agro Crop Sci., 201:280-287.

Apel, K. and H. Hirt (2004). Reactive oxygen species: metabolism, oxidative stress, and signal transduction. Annu. Rev. Plant Biol., 55: 373-399.

Cattivelli, L., F. Rizza, F.W. Badeck, E. Mazzucotelli, A.M. Mastrangelo, E. Francia, C. Mare, A. Tondelli and A.M. Stanca (2008). Drought tolerance improvement in crop plants: An integrative view from breeding to genomics, Field Crop. Res., 105, 1-14.

Eldemery, S.M.M., K.F. Abdellatif, E.A. ElAbsawy and H.A. Emara (2016). Gene expression induced in faba bean (Vicia faba L.) by (Orobanche crennata) and its impact on the field level. Egyptian Journal of Genetics and Cytology 45 (2), 279-295.

El-Rabey, H., K.F. Abdellatif and Y.A. Khidr (2009). Cytogenetical and biochemical charagterizationof some egyption barly (Hordeum vulgare L.) cultivars. Australian Journal of Basic and Applied Sciences 3 (2), 644-651.

El-Absawy, E.A., A.M. Zakaria and K.F. Abdellatif (2012). Determination of genetic diversity of some faba bean (Vicia faba L.) varieties using morphological traits and molecular markers. Minufiya J. Agric. Res. 374 (1): 843-853.

Elsawy, M.F., D. El-Naggar, S.A. Elabsawy, Y.M. Yassen and K.F. Abdellatif (2015). Biochemical and pathological characterization of leaf rust resistance in some Egyptian wheat cultivars. Minufiya J. Agric. Res., 40 (1), 79-88.

Khan, H. R., J. G. Paull, K .H. M. Siddique and F. L. Stoddard (2010). Faba bean breeding for drought-affected environments: A physiological and agronomic perspective. Field Crops Res., 115, 279-286.

Laemmli, U. K. (1970). Cleavage of structural proteins during the assembly of the head of bacteriophage T4. Nature, 227: 680685.

Leht, M. (2009). Phylogenetics of Vicia (Fabaceae) based on morphological data. Feddes Repertorium 120 7-8, 379-393.

Link, W., A.A. Abdelmula, E.V. Kittlitz, S. Bruns, H. Riemer and D. Stelling (1999). Genotypic variation for drought tolerance in (Vicia faba.L) Plant Breed., 118:477-483.

McDonald, G. K. and G.M. Paulsen (1997). High temperature effects on photosynthesis and water relations of grain legumes. Plant Soil, 196:47-58

Musallam, I.W., G. Al-Karaki, K. Ereifej and A. Al-Tawaha (2004). Yield and yield components of faba bean genotypes under rainfed and irrigation conditions. Asian J. of Plant Sci., 3: 439-448.

Ouda, S.A., M.A. Shreif and R. Abou Elenin (2010). Increasing water productivity of faba bean grown under deficit irrigation at middle Egypt. Proceedings of the 14th International Water Technology Conference, March 21-23, 2010, Cairo, Egypt 345-355.

Ouji, A., M. Rouaissi, R. Abdellaoui and M. EI Gazzah (2011). The use of reproductive vigor descriptors in 
studying genetic variability in nine Tunisian faba bean (Vicia faba. L) Populations. African J. of Biotechnology. 10: 896-904.

Patrick, J.W and Stoddard F.L (2010). Physiology of flowering and grain filling in faba bean. Field Crops Research, 115: 234-242.

Rohlf, F. J. (2000). NTSYSpc. Numerical taxonomy and multivariate analysis system, version 2.02c. Exeter Software, New York.

Sall, J., L. Creihton and A. Lehman (2007). JMP Start Statistics: A Guide to Statistics and Data Analysis Using JMP and JMP-IN Software. SAS Institute, Cary, NC.

Shaddad, M.A. and M.A. El-Tayeb (1990). Interactive effects of soil moisture content and hormonal treatment on dry matter and pigments content of some crop plants. Acta Agron. Hung., 39, 49- 57.

Siddiqui, M.H., M.Y. Al-Khaishany, M.A. Al-Qutami, M.H. Al-Whaibi, A. Grover and H.M. Ali (2015). Morphological and physiological characterization of different genotypes of faba bean under heat stress. Saudi J Biol Sci., 22:656-63.

Stegmann, H.W., A.E.T. Shehata and M. Hamza (1980). Broad bean proteins
(Vicia faba L.) Electrophoresis studies on seeds of some German and Egyptian cultivars. Zeitschrift fur Acker-Und Pflanzenbau. J. Agronomy. (6): 446-454.

Stoddard, F.L., C. Balko, W. Erskine, H.R. Khan, W. Link and A. Sarker (2006). Screening techniques and sources of resistance to abiotic stresses in coolseason food legumes. Euphytica, 147:167-186.

Terzopoulos, P. J. and P. J. Bebeli (2008). Genetic diversity analysis of Mediterranean faba bean (Vicia faba L.) with ISSR markers. Field Crops Res., 108: 39-44.

Zakaria, A.M., S.A.F. El-Okkiah, S.M.M. Eldemery, H.A. Emara, E.S.A. ElAbsawy and K.F. Abdellatif (2015). Morphological, physiological. Histological and biochemical characteristics of faba bean (Vicia faba L.) infected by Broomrape (Orobanche crennata). J. Agric. Res. Kafr El-Sheikh Univ., 41 (4), 1073-1093.

Zlatev, Z. and F. C. Lidon (2012). An overview on drought induced changes in plant growth, water relations and photosynthesis. Emirates. J. Food Agric., 24: 57-72. 
الاختلافات الظاهرية والكيموحيوية واستجابة الفول البلدي المصري للحرارة والجفاف

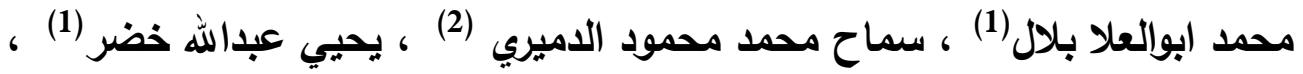
كمال فؤاد عبداللطيف (1)

(1) قسم البيوتكنولوجيا النباتيه، معهد بحوث الهندسة الوراثية والتكنولوجيا الحيوية - جامعه مدينه السادات - المنوفيه- مصر . (2) قسم البيولوجيا الجزيئيه، معهل بحوث الهندسة الوراثية والتكنولوجيا الحيوية - جامعه مدينه السادات - المنوفيه- مصر .

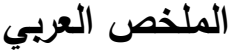

تم تقيم أريع أصناف من الفول البلاي تحت ظروف الجفاف والحرارة باستذام 17 صفة مورفولوجية ومحتوي

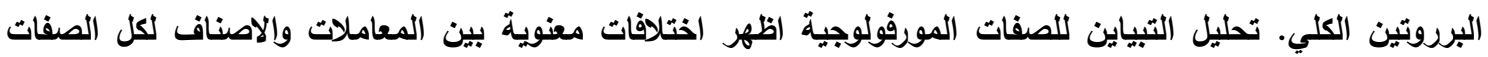

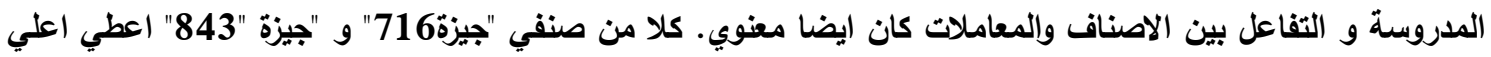

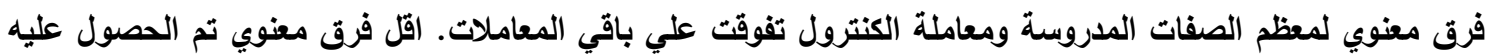

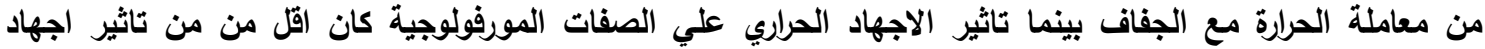

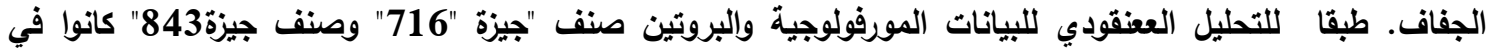

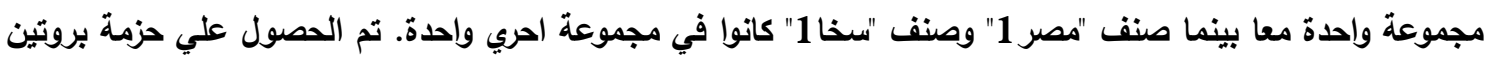

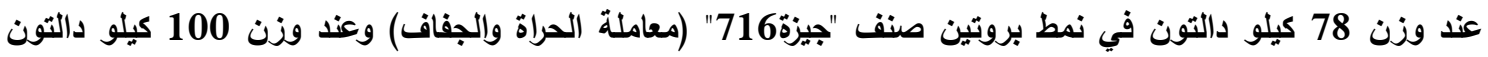

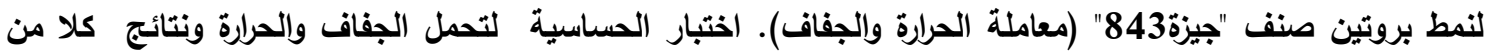

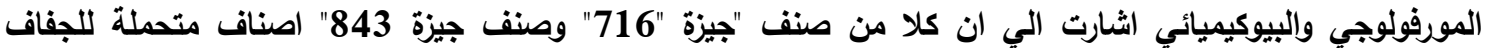
والحرارة بينما صنف "مصر 1" وصنف "سخا 1" اصناف حساسة للجفاف والحرارة. 
M. A. Belal, et al., 